\title{
Прелімінарна матриця соцреалістичної парадигми «дитя революції»
}

Досліджується питання соціального вигнанства дитини (сирітства / безпритульності) в його онтологічнолу значенні. Розглядається особливості фборлування виокрелленої парадигми "дитя революиї̈. Образ знедоленої дитини - інтерпретується, як перше втілення даної парадигми в літературі. Прослідковуеться специфбіка фборлуванння парадигли "дитя революиї̈, та вплив на ие явище суспільно-історичних потрясінь. Вивчається прелілінарна кризова передісторія дитячої особистості в уловах революиї як соціальної травли. Слерть дитини, піднесеної спільною справою (або захопленою новою державною ідеєю), інтерпретується як транзитивний образ європейської повоєнної літератури нового часу.

Ключові слова: "дитя революиї̈", сочреалізл, ідеологіл, революиія, дитина-сирота, В. Гюго, Е. Багрицький, Велика Французька революиія.

Постановка проблели в загальнолу вигляді...Соціальне зло в образі злиднів, виснажлива дитяча праця, безпритульність дитини на тлі світу дорослих - це ті провідні теми літератури ХІХ ст., що відтворюють всесвіт маленького героя-невдахи. Літературиний образ дитини-сироти стае одним із найбільш поширених під впливом соціальних зрушень Великої французької революції і постає як тема знедолених саме в европейській літературі XIX ст. Автори, які зверталися до теми знедоленого дитинства, чимраз наполегливіше підкреслюють світоглядну й соціальну проблематику сирітства, визначену новою історичною добою та їі основними конфліктами. Класичними зразками в цьому значенні постають тексти Ч. Діккенса «Олівер Твіст» (1838 р.), А. Доде «Малюк» (1868 р.), Г. Мало «Без сім'і» (1878 р.), Ж. Валлеса «Дитинство» (1878 р.), Ф. Достоєвського «Неточка 
Незванова» (1849 р.) і “Хлопчик у Христа на ялинці» (1876 р.), Д. Григоровича «Гутаперчевий хлопчик» (1883р.), М. Твена «Том Сойер і Гекльберрі Фінн» (1884р.), В. Короленка «Діти підземелля» (1885 р.) та ряд ін.

Аналіз досліджень $і$ публікацій... Літературну інтерпретацію теми сирітського дитинства розглядали О. Січкар [11, с. 259-261], О. Бухіна [3, с. 374-397], американська дослідниця в галузі психології Керол Пірсон, зокрема, ідентифікуе так званий архетип сироти: «Архетип сироти в кожному з нас пробуджуеться через усі такі життеві ситуації, коли дитина всередині нас відчуває себе залишеною, покинутою, зрадженою, забутою чи розчарованою» [13, с. 83]. Знаходимо міркування про цей міфологічний архетип у американської письменниці Террі Уіндлінг: «Герой-сирота $є$ не лише уявним образом, що зустрічається часто-густо, це радше мірологічний архетип, що бере початок у найдавніших історіях нашого світу. Цей архетип включає в себе не тільки тих героїв, які в буквальному сенсі стали сиротами після смерті обох батьків, а й тих дітей, які були вигнані, залишені, загублені, позбавлені спадщини злими названими батьками, виховані в чарівному полоні, вирощені дикими тваринами» (див.: [14]). Згадана проблема висвітлюеться також у ряді інших наукових розвідок.

Форлулювання иілей статmі... Мета статmі - проаналізувати основні екзистенційні принципи формування парадигми «дитя революції» у знакових літературних прикладах.

Виклад основного матеріалу... Аналізуючи літературні образи XIX ст., О. Бухіна зауважує: «Образ сироти ідеально «вбирає» в себе життеві цінності й уявлення про добро та зло. Навіть на обмеженій кількості прикладів легко переконатися, наскільки різниться сприйняття «доброго» сироти в різних країнах, насамперед, у плані активності або пасивності життевої позиції, необхідності моральних змін. Не менш разюче відрізняються очікування соціуму, що обіцяють «гидкому каченяті» урочисту перемогу або гірку поразку» [3, с. 397]. Осібно відзначимо тему сирітства у творчості Т. Шевченка найбільш виразна вона в таких його віршах, як «Тяжко-важко в світі жити» (1838 р.), «Мені тринадцятий минало...» (1847р.), «Ой умер старий батько» (1848р.). Відзначимо, що вже в першому із вищеназваних поетичних текстів звучить мотив самогубства:

Тяжко-важко в світі жити

Сироті без роду,

Нема куди прихилиться -

Хоч з гори та в воду. 
Утопився б молоденький,

Щоб не нудить світом,

Утопився б - тяжко жити,

А нема де дітись [12, с. 82-83].

Проте ліричний герой замість цього обирає чужину, яку фрактично читач може інтерпретувати, як те ж саме самогубство:

Шукав долі в чужім полі

Та там і загинув.

Умираючи, дивився,

Де сонечко сяе.

Тяжко-важко умирати

У чужому краю... [12, с. 82-83].

Образи емоційного та екзистенційного станів сироти з'являються в европейській літературі XIX ст. унаслідок історичної кризи, спровокованої Великою французькою революцією. Зразковим прикладом тут постає літературна спадщина В. Гюго, яка має непроминущу гуманістичну значущість, зокрема завдяки тому, що закликае до людського милосердя i співчуття. Величезний літературний і громадянський авторитет В. Гюго у його сучасників передбачав і наслідування відкритих письменником тем.

За радянських часів дослідники творчості В. Гюго, з посиланням на літературні авторитети, подавали його читачам в особливому статусі: як геніального співця та натхненника французьких революційних рухів XIX ст. Справді, революційні мотиви захоплювали В. Гюго, не байдужого до історичних подій свого часу. Проте ці події цікавили поета не самі по собі, а передусім як фактор, що руйнує людську долю. Так, Н. Гукасян, з посиланням на біографів В. Гюго, відзначае, що письменник був частим відвідувачем робітничих кварталів, переймався гірким життям їх мешканців (див.: [5]). 3 його спостережень над життям паризьких гаменів виник один із найяскравіших дитячих образів художника - образ Гавроша, що, за словами Н. Гукасян, «підкуповуе своєю дитячою наївністю, запальною іронією, веселістю, нахабністю, серцем, здатним відгукнутись на будь-яке людське горе» [там само].

Діти в романах В. Гюго - це переважно втілення образу дитячої безпритульності. Героїчна смерть хлопчика «на барикадах» стала одним із символів Великої фрранцузької революції. Трагізм смерті Гавроша жахливий тим, що, по-перше, це смерть підлітка, життя якого тільки почалось, по-друге, це неусвідомлена смерть дитини, яка не 
здатна, через свій юний вік й власний життевий досвід, адекватно виважити небезпечність ситуації, в якій вона опиняеться, i, по-трете, момент небезпеки і власної загибелі Гаврош сприймає як гру.

Образ Гавроша слушно конотуе зі спостереженнями Т. Лопушан, яка вже на прикладах української літератури в аспекті антропологічної парадигми «ініціація» розглядає проблеми, пов'язані 3 дитячими трагедіями. Дослідниця зауважуе, що «проблеми входження дитини, як людської особистості, в контекст суспільного буття 3 його віками виробленою системою моральних i культурних цінностей» супроводжується «ритуалом ініціацій, що належить до великої групи обрядів переходу, метою яких було - дати можливість індивіду перейти від одніеї соціальної позиції до іншої. Саме таким чином відбуваеться входження дитини у світ дорослих цінностей» [8, с. 2]. Питання соціального вигнанства дитини (сирітства / безпритульності) в онтологічному значенні може бути розглянуте як один із рушійних факторів формування виокремленої тут парадигми «дитя революції. Нова світоглядна ситуація дозволяе по-новому інтепретувати цю позицію. Образ знедоленого Гавроша - перше втілення й парадигми «дитя револющіï» в літературі. Революційна ідея інтерпретуе дитинуянгола як дитину-воїна, тим самим спрощуе образ дитини, не спроможна пояснити її онтологічний статус.

Тематичну рамку «доля дитини в умовах воєнного часу» (див.: [4]) в різних сюжетних аспектах продовжували заповнювати поети та письменники радянської літератури. Насамперед сюди входять такі класичні зразки, як роман М. Островського «Як гартувалася сталь» (1932 р.), твори А. Гайдара «Мальчиш-Кібальчиш» (1933 р.), «Тимур та його команда» (1940р.), роман О. Фадеева «Молода гвардія» (1946 р.), повість В. Катаєва «Син полку» (1944р.) та ін. Таким чином, у радянській літературі першої пол. ХХ ст. парадигма «дитя революції» активно втілюються в нових героях - юних революціонерах.

Так, у романі М. Островського «Як гартувалася сталь» головний герой Павка Корчагін на початку твору постае «черноглазым в серенькой рубашке и синих штанах с заплатами на коленях» [9, с. 12], якому, підкреслюється у книзі, «по Закону Божию поп всегда ставил пять. Все тропари, Новый и Ветхий завет знал он назубок; твердо знал, в какой день что произведено Богом» [9, с. 13]. Однак через конфлікт 3 учителем Павлушу виганяють зі школи, і починається період складного становлення особистості майбутнього героя революції, «сталь починає загартовуватись», з віруючого хлопчика Корчагін перетворюеться на молодого комуніста. Настанову Павка Корчагін отримуе від 
більшовицького товариша, матроса Федіра Жухрая:

«Я, братишка, в детстве тоже был вроде тебя, - говорил он. - Не знал, куда силенки девать, выпирала из меня наружу непокорная натура. Жил в бедности <..>. Я тебе, братишка, расскажу про настоящую дорогу, потому что знаю: будет из тебя толк. Тихоньких да примазанных не терплю. Теперь на всей земле пожар начался. Восстали рабы и старую жизнь должны пустить на дно. Но для этого нужна братва отважная, не маменькины сынки, а народ крепкой породы, который перед дракой не лезет в щели, как таракан от света, а бьет без пощады» [9, с. 77-78].

Так започатковуеться образ «дитини революції» в радянській класиці. Одночасно з романом М. Островського в радянській літературі з'являеться ще один приклад «дитини революції» (у сучасній рецепції безмірно трагічний): дівчинка-піонерка Валентина 3 поеми радянського поета Е. Багрицького «Смерть піонерки» (1932). За радянських часів «Валя-Валентина" десятиліттями входила до обов'язкової шкільної програми, текст вчили напам'ять, він звучав у кінострічках (фільм «Дика собака Дінго», 1962 р.). За сюжетом ця дівчинка, яка помирає в лікарні, незважаючи на благання матері одягнути рятівний хрестик, героїчно опирається материнському благанню до смерті, марячи звуками піонерського горну та мрією здійняти червоний прапор на фрлагштоці:

В прозелень лужайки

Капли как польют!

Валя в синей майке

Отдает салют.

Тихо подымается,

Призрачно-легка,

Над больничной койкой

Детская рука.

«Я всегда готова!» -

Слышится окрест.

На плетеный коврик

Упадает крест.

И потом бессильная

Валится рука

В пухлые подушки,

В мякоть тюфяка [1, с. 18].

Піонерка Валентина - це «радянський Гаврош», але якщо Гаврош 
помирає на реальній барикаді, то для Валентини «барикадою» стає лікарняне ліжко та материнські сльози.

У статті А. Бойчук про латентний атеїзм дитячої літератури радянського часу підкреслюеться, що «партійна стратегія соціалістичного реалізму активно й жорстко проводила свою виховну практику: починаючи від літератури для дітей, яка потерпала <...> від селекції потрібних дитині тем, мотивів, образів. Така дитяча література втрачала не лише свою креативну самобутність, але й мислячого адресата. Вона ставала потужним інструментом тотальної ідеологізації суспільства, її світоглядною програмою було очищення свідомості юного покоління від віри в Бога» [2, с. 70].

Гаврош безпритульний, він сирота, і його участь у революції зумовлена відсутністю даху над головою, але ж Валентина свідомо відмовляеться від хреста (відповідно - Христа) заради своїх побратимівпіонерів, іiі бажанням стає підтримання революційного духу в інших однолітках (однодумцях). Образ цієї дівчинки рішуче пропагуе атеїзм, формуе необхідний новій владі ідеологічний світогляд. Статус «дитини революції» в цьому прикладі демонструе «інший» екзистенційний стан: 1) духовне сирітство 2) жага смерті заради ідеї. За таких умов слова 3 поеми сприймаються як грандіозне і жахливе жертвоприношення, як висновують тепер О. Лекманов та М. Свердлов (див.: [7]), слова являють «чорну формулу» (визначення О. Лекманова), відповідно до якої мають померти якомога більше людей, щоб усю землю напоїти кров'ю заради нового життя:

Чтоб земля суровая

Кровью истекла,

Чтобы юность новая

Из костей взошла [1, с. 19].

За висновком О. Лекманова і М. Свердлова, «мова йде про заклик «непримусово принести свое тіло в жертву революційної стихії. <..> Оновлення життя потребує все нових смертей; його чудодійний ресурс та енергія, яка народжуеться з принесення дівчинкою Валею себе у жертву» [7]. Героїзація трагедії піонерки (смерть від хвороби) практично підноситься на один щабель із героїчною загибеллю, акцент робиться не на обставинах, що спричиняють смерть, а на характері самої людини, на їі виборі в даній ситуації.

Гаврош стрибає поміж мерців, витанцьовуе, показуе довгого носа своїм ворогам; Валентина, помираючи, розчиняеться у думках про звуки піонерського горну. Жоден із них, унаслідок своїх вікових 
особливостей, не думає про смерть, тобто не можна вважати їхні фрінальні «героїчні» вчинки свідомими. "Дитина, - як констатуе фрілософр В. Зеньковський, - насправді, не володіє своєю активністю і тому, за спільним загальнолюдським переконанням, не відповідае за неї ні перед людьми, ні перед Богом. «Невинність» дитячої душі виражае те, що діти у своїй емпіричній особистості не є справжніми суб'єктами свого життя, їх свідомість не збентежена ще моральною самоперевіркою; лише в почуттях сорому i совісті, як у почуттях, що сходять своїм корінням до неемпіричної сторони душі, - закладаються перші емпіричні основи самооцінки, перші зачатки віднесення своїх «вчинків» саме до емпіричності власної особистості» [6, с. 343]. Суголосна думка сучасного британського дослідника Дж. Севіджа: «Тільки юність легко розлучаеться з життям. Вона ще не пов'язана із земним існуванням тисячами тих ниток, якими ми пов'язані з громадянським буттям. Юність ще не навчилася економно витрачати час життя. Вона піднімається на гору і не бачить, який короткий наступний спуск. Жага пригод робить юність завзятою, i вона йде в бій із задоволенням i безпечністю» [10, с. 44].

Героїчні діти згаданих творів прочитуються в аспекті тематичної парадигми «дитя революції. Кожен із них виконуе свою ідеологічну фрункцію, яка е транзитивною моделлю розглянутої нами парадигми. За словами В. Зеньковського, «недоросток унаслідок свого статусу дитини сприймає свої вчинки, свою діяльність як свого роду гру, ніби вживається в роль, не усвідомлюючи ситуації до кінця, психіка дитини не здатна усвідомлювати наслідки своїх дій, а тільки грає щиро, відчайдушно, старанно, натхненно, із запалом, оскільки не може зрозуміти жаху можливої перспективи смерті» [6, с. 54].

Дж. Севідж привертає увагу до цікавого соціологічного опитування столітньої давнини, здійсненого групою молодих учених, які сховали свої імена під псевдонімом Агатон. Опитування проводилось серед молодих людей віком від 18-ти до 25-ти років. Як вважає дослідник, це була «одна з багатьох спроб у передвоенний період (на поч. XX ст.) створити в Європі нові молодіжні рухи» [10, с. 44]. Результати опитування були опубліковані у Парижі напередодні Першої світової війни у форматі книги-брошюри «Молодь сьогодення (Agathon)/»Les jeuns gens d'aujourd'hui» (1913 р.). Згідно із результатами опитування, тогочасне нове покоління відрізнялось від попередніх такими характерними рисами: "смак до дії, "патріотична віра», "католицьке відродження», «політичний реалізм» [10, с. 43-44, 176]. «До цього часу, - за словами дослідника, - юність була країною, керованою дорослими, 
- тепер підопічні вимагали права голосу. В трактаті Агатона позбавлена прав юність як така була зведена в статус релігї. <...> Результати дослідження показали ідейну готовність тодішньої фрранцузької молоді до війни і до револющїі» [10, с. 176].

Висновки... Як бачимо, за умов ідеологічної активності трагізм дитячого стану полягає в тому, що захоплена любов'ю до ідеї дитина здатна піти на смерть - це можна трактувати як неусвідомлене самогубство. Аналіз екзистенщійних підвалин юнацької поведінки у розглянутих літературних прикладах підтверджує висновок В. Зеньковського: "Дитяча ірращіональність - зворотний бік того, що в дитячій душі домінує емоційна сфера: інтелект і воля займають друге, суто службове місце, справжній центр особистості лежить глибше них» [6, с. 345-346].

Отже, парадигма «дитя револющії», що виникла у Франщії під впливом суспільно-історичних потрясінь, виявляється плідною для наступного аналізу як перша (прелімінарна) кризова передісторія особистості. Кожен персонаж втілює різні акценти трагедї революції як соціальної травми, але, хоча Гаврош гине на барикадах, Валентина помирає на лікарняному ліжку, в обох випадках ми бачимо спільне: смерть дитини постає основним екзистенщійним фрактом парадигми «дитя революції». Таким чином, смерть дитини, піднесеної спільною справою (або захопленою новою державною ідеєю), може інтерпретуватися як транзитивний образ європейської повоєнної літератури нового часу.

\section{Список використаних джерел і літератури:}

1. Багрицкий Э. Смерть пионерки. Москва : Молодая гвардия, 1961. 32 с.

2. Бойчук А. Латентний атеїзм дитячої літератури радянського часу. Питання літературознавства. 2015. Вип. 77. URL: https://www.researchgate.net/publication/324561921_Latentnij_ateizm_di tacoi_literaturi_radanskogo_casu (дата звернення 11.01.2020)

3. Бухина О. Чего может добиться гадкий утенок: психологический портрет сироты в детской литературе. Конструируя детское. Филология, история, ант ропология /под ред. М. Р. Балиной, В. Г. Безрогова, С. Г. Маслинской. Москва, Санкт-Петербург : Азимут, Нестор-История, 2011. С. 374-397.

4. Головій О. Дитина у воєнних умовах на сторінках української літератури (оповідання I. Багряного «Пацан» та повість Гр. Тютюнника «Климко»). Актуальні проблели слов'янської ббілології. Серія: Лінгвістика $i$ літературознавство : міжвуз. зб. наук. ст. 2009. Вип. 21. С. 360-372.

5. Гукасян Н.

Тема детства во фрранцузкой литературной традиции и творчестве В.

Гюго. Вопр. фбилологии.

Ереван 
Лингва, 2003. Вып. 1. URL: http://19v-euro-lit.niv.ru/19v-euro-lit/articlesfra/gukasyan-tema-detstva-gyugo.htm (дата звернення 05.01.2020)

6. Зеньковский В. Психология детства. Лейпциг : Сотрудник, 1924. 348 c. URL: http://www.xpa-spb.ru/libr/Zenkovskij/psihologiya-detstva-1924-

1.html (дата звернення 03.01.2020) 2017.

7. Лекманов О., Свердлов М. Для кого умерла Валентина? Новый мир.

URL: http://www.nm1925.ru/Archive/Journal6_2017_6/Content/Publication6_6654/ Default.aspx (дата звернення 03.01.2020)

8. Лопушан Т. Особливості розкриття проблеми ініціації дитини в українській новелістиці порубіжжя XIX-XX століть. Актуальні проблели слов'янської фбілології. Серія: Лінгвістика і літературознавство : міжвуз. зб. наук. ст. 2009. Вип. 21. С. 149-156.

9. Островский Н. Как закалялась сталь. Киев : Веселка, 1986. 348 с.

10. Севидж Дж. Тинейджеры. Зарождение молодежной культуры: 18751945. Москва. Белое яблоко, 2017. 630 с.

11. Січкар О. Проблема сирітства в українській літературі для дітей і про дітей кінця XIX - початку XX століття. Сучасні проблеми мовознавства та літературознавства : зб. наук. пр. /відп. ред. І. В. Сабадош. Ужгород, 2011. Вип. 15. С. 259-261.

12. Шевченко Т. Зібр. Творів : у 6 т. Киӥв, 2003. Т. 1. 784 с.

13. Pearson C. Awakening the Heroes Within. TwelveArchetypes to Help Us Fi nd Ourselves and Transform OurWorld. N.Y.: HarperOne, 1991. 352 p.

14. Windling T. Lost and Found: The Orphaned Hero in Myth, Folklore, and F antasy. URL: https://www.terriwindling.com/folklore/orphaned-hero.html (дата звернення 05.01.2020)

\section{References:}

1. Bagry`czky`j Э. (1961). Smert` py`onerky`. [Pioneer Death]. Moskva : Molodayagvardy`ya, 1961. 32 s. [in Russian]

2. Bojchuk A. (2015). Latentny`j ateyizm dy`tyachoyi literatury` radyans `kogo chasu. Py`tannya literaturoznavstva. [Latent atheism of Soviet-era children's literature. Questions of Literary Studies]. 2015. Vy`p. 92. S. 61-77. URL: https://www.researchgate.net/publication/324561921_Latentnij_ateizm_ditac oi_literaturi_radanskogo_casu (data zvernennya11.01.2020). [in Ukrainian]

3. Buxy`na O. Chego mozhet doby`t’sya gadky`j utenok: psy`xology`chesky`j portret sy`rotы $\mathrm{v}$ detskoj ly`terature. Konstruy`ruya detskoe. Fy`lology`ya, y`story`ya, antropology`ya /pod red. M. R. Baly`noj, V. G. Bezrogova, S. G. Masly`nskoj. Moskva, Sankt-Peterburg : Azy`mut, Nestor-Y`story`ya, 2011. S. 374397.

4. Golovij O. Dy`ty`na u voyenny`x umovax na storinkax ukrayins koyi literatury` (opovidannya I. Bagryanogo «Paczan» ta povist` Gr. Tyutyunny`ka «Kly`mko»). Aktual`ni problemy` slov'yans`koyi filologiyi. Seriya: Lingvisty`ka i literaturoznavstvo : mizhvuz. zb. nauk. st. 2009. Vy`p. 21. S. 360-372. 
5. Gukasyan N. Tema detstva vo franczuzkoj ly`teraturnoj trady`cy`y' y' tvorchestve V. Gyugo. Vopr. fy`lology`y`. Erevan : Ly`ngva, 2003. Vыр. 1. URL: http://19v-euro-lit.niv.ru/19v-euro-lit/articles-fra/gukasyan-tema-detstva-gyugo.htm (data zvernennya 05.01.2020)

6. Zen`kovsky`j V. Psy`xology`ya detstva. Lejpcy`g : Sotrudny`k, 1924. 348 s. URL: http://www.xpa-spb.ru/libr/Zenkovskij/psihologiya-detstva-1924-1.html (data zvernennya 03.01.2020)

7. Lekmanov O., Sverdlov M. Dlya kogo umerla Valenty`na? Novыj my`r. 2017. \#

URL:http://www.nm1925.ru/Archive/Journal6_2017_6/Content/Publication6_6654/ Default.aspx (data zvernennya 03.01.2020)

8. Lopushan T. Osobly`vosti rozkry`ttya problemy` iniciaciyi dy`ty`ny` $v$ ukrayins`kij novelisty`ci porubizhzhya XIX-XX stolit`. Aktual’ni problemy` slov'yans`koyi filologiyi. Seriya: Lingvisty`ka i literaturoznavstvo : mizhvuz. zb. nauk. st. 2009. Vy`p. 21. S. 149-156.

9. Ostrovsky`j N. Kak zakalyalas`stal`. Ky`ev : Veselka, 1986. 348 s.

10. Sevy`dzh Dzh. Ty`nejdzherы. Zarozhdeny`e molodezhnoj kul`turы: 18751945. Moskva. Beloe yabloko, 2017. $630 \mathrm{~s}$.

11. Sichkar O. Problema sy`ritstva v ukrayins`kij literaturi dlya ditej i pro ditej kincya XIX - pochatku XX stolittya. Suchasni problemy` movoznavstva ta literaturoznavstva : zb. nauk. pr. /vidp. red. I. V. Sabadosh. Uzhgorod, 2011. Vy`p. 15. S. 259-261.

12. Shevchenko T. Zibr. Tvoriv : u 6 t. Ky`yiv, 2003. T. 1. 784 s.

13. Pearson C. Awakening the Heroes Within. TwelveArchetypes to Help Us Find Ourselves and Transform OurWorld. N.Y.: HarperOne, 1991. 352 p.

14. Windling T. Lost and Found: The Orphaned Hero in Myth, Folklore, and Fantasy. URL: https://www.terriwindling.com/folklore/orphaned-hero.html (data zvernennya 05.01.2020)

\section{Summary \\ Yulia Vilchanska, Victoria Zavydovych}

The Primary Matrix of the Social Realistic Paradigm "Child of Revolution"

This article discovers the question of social exile of a child (orphanage / homelessness) in its ontological meaning. The peculiarities of formation of the isolated paradigm "child of revolution" are considered. In addition, it considers the peculiarities of formation of divided paradigm "child of revolution". The status of "child of the revolution" demonstrates a "different" existential position: 1) spiritual orphanage; 2) the thirst for death for the sake of the idea. It is determined that, due to conditions of ideological activity, the child in a passionate love to the idea is capable to go to death; the last can be explained as unconscious suicide. The existential foundations of youthful behavior are analyzed in the prominent literary examples: V. Hugo's homeless teenager Gavrosh, M. Ostrovskyi's young revolutionary Pavlo Korchagin, and E. Bagrytskyi's pioneer girl Valentyna. The question arises about children's irrationality and the causes of tragedy of the 
child's condition. Also in this article, such questions are traced: the specificity of the formation of the paradigm "child of the revolution", and the impact of social and historical upheavals on this phenomenon. Besides, the primary prehistory crisis of child's personality in conditions of revolution that can be seen as social trauma is being studied. The main existential factors of the paradigm "child of revolution" are analyzed. The death of a child brought up by a common cause (or captured by a new state idea) is interpreted as a transitive image of modern European postwar literature.

Key words: "child of revolution", social realism, ideology, revolution, The French Revolution, orphan, V. Hugo, M. Ostrovskyi, E. Bagrytskyi.

Дата надходження статті: «12» грудня 2019 р.

Дата прийняття до друку: «22» січня 2020 р.

\section{УДК 821.161.2'82-32:82-4 \\ DOI: 10.31475/fil.dys.2020.10.03}

НАДІЯ ГАСВСЬКА, кандидат фбілологічних наук, пробесор (м. Kü̈);

ОЛЕНА ГАСВСЬКА, кандидат фбілологічних наук, доцент (л. Київ)

\section{Жанрова система малих епічних форм Олеся Гончара}

У статті розглядаються особливості малих епічних фборл $у$ доробку О. Гончара. З'ясовуеться специфбіка жанрової природи малої прози письленника, розкриваються телатичні, стильові, образні особливості показових для творчості мития новел та оповідань, аналізуються зображально-виражальні засоби (портрет, пейзаж, деталізація, наративні бборли тощо). Окрелу увагу приділено особливостял малих борл публіцистики О. Гончара, зокрела жанру нарису. Акцентовано на проблелних питаннях теорії художніх та публіцистичних жанрів. Доведено, шо особливості жанротворення й трансборлацї жанрової структури малих епічних бборл у доробку О. Гончара обуловлювалися появою нових тел, які актуалізували національні, соціальні, морально-етичні, естетичні проблели суспільства, що вимагали адекватної бборли та засобів художнього втілення. Встановлено, що О. Гончар у малій прозі притрилувався приниипів реалізму, ролантизму, психологізму, докуленталізму й 